\title{
The Main Vector of Ukrainian Politprognozy
}

\section{V.Kuzevanov}

\begin{abstract}
The forecast of possible options for the future transformation of Ukrainian politics is based on a comparative analysis of the causes of political crises and civil wars in the twentieth century in Ukraine, and XXI centuries in connection with the foreign factors and the author's methodology postakademizma. It is also considered two main options for Ukrainian politicians in the next 20 years: the military and democratic. Including the effects of the military aggression of Russia in Ukraine.
\end{abstract}

Tags: author's methodology postakademizma, Ukrainian political crisis, civil war, the consequences of military aggression of Russia

\section{Introduction to the Problem}

A key and important issue in the study of modern political and democratic transformation in Ukraine today is the question: how long will the process of perception of European democratic values and the approval of the national sovereignty of all Ukrainian society, in all regions of Ukraine. Including the question arises: "Ta Chi soon zdobude absolutely Peremoga UKRAINE yak samostiyna democratic that" absolutely Square "in svoïh prioritetah power?" [3, p.38]. And the question "When will win the victory?" Need to integrate with the question, "How long in Ukraine will continue the civil war (or ATO or military aggression of the neighboring state) in the east of Ukraine?". Since the perception of European democratic values and the assertion of national sovereignty is impossible in conditions of civil war (or ATO or military aggression), when Ukraine annexed the Crimea and eastern regions of Donbass. In accordance with the above-mentioned problem should be considered existing in Ukrainian political science different methodologies, techniques and approaches to predict the next 1520 years the characterization of possible political processes of transformation and democratization of the Ukrainian political system, in conjunction with the assertion of national sovereignty, and to predict the role of Ukraine in the world political circles as possible and the civil war (or ATO or war with Russia).

\section{ANALySIS OF EXISTING RESEARCH}

Any empirical study and prediction of the main stages and the newest political history of Ukraine should be based on a theoretical and methodological rationale of this study, including based on civilizational and systemic approaches. For example, a systematic approach to identify key external and internal factors of transformation of the Ukrainian political system presupposes not only the existence of an international "balance of power" major national actors in international politics $[6, \mathrm{p}$. 452], but even effect of external and internal factors of transformation of the Ukrainian political system at present and in the near future. And not to assume that everything occurring today and in the near future in Ukrainian politics (and in European and in world too) is completely, utterly devoid of logical sense and political forecast.

Scientifically sound forecast, with a high level of theoretical and methodological basis, is a historical analysis of previous and future history of Ukraine, as set out in the monograph Yu.Pavlenko [18]. Including the study of civilizational structure of the former Soviet Union, he said that Russia, Ukraine and Byelorussia due to the deep economic and civilizational differences in principle not able to integrate into the Western world [18, p.650]. Because "civilizational nature of these countries is deeply eroded and deformed dropped out on their share of tragic experiments of the twentieth century." [18, p.650].

In the same studies that predicted the future of Ukraine integration into the Western world, the European Union, there is no theoretical and methodological basis and the social, political and economic conditions and the possibility of the need to integrate into the European Union. For 


\section{V.Kuzevanov}

example, in the study of the process of modernization of civil society is marked not only the lack of theoretical justification of the modernization process, but the lack of a social force capable of independently lead the modernization process [16, p.38].

Returning to existing prognostic political science and social science research, it is also necessary to note the absence of specific terms the duration of the Ukrainian crisis and the Civil War (ATO) and in other publications of political science, as well as in sociological forecast studies. For example, the forecast duration of the sociologist E.Kopytko not release terms of the political crisis, and the economic collapse of the anti-stress state of the Ukrainian society. Including no flow periods following negative trends: "Against this background, will operate all the trends at the same time - and the conflict in power, and activation of the new nascent opposition, and active intervention in the internal affairs of the country of our foreign colleagues' [24].

In more objective research on the possible dates and vectors of development of the Ukrainian political system in the coming decades, there is no rosy picture solemn Ukrainian integration into the Western world, in the European Union. For example, Doctor of Social Sciences Shedyakov VE He notes two main vectors in the short term, the political system of Ukraine: the transformation of a second-rate country or psevdozapadnuyu revival based on their own values and meanings complexes of its cultural and civilizational world headship advanced technologies postmodernity [22, p.251]. But before reviving Ukrainian cultural-civilizational world, you must first find out what the world was in the twentieth century. and why we lost it. And only then we will be able to more objectively predict the size of future political system. And on the "headship advanced technologies postmodernity" Ukraine needs to wait at least 20-25 years to change the existing political system and retired the current political elite. And to come into power young reformers. For example, our contemporary, Advisor to the Minister of Education and Science, $\mathrm{PhD}$ Victor Galasyuk calls "rent from raw materials industries should be consciously directed to the development of high-tech industries that can feed us after 8-10 years is much higher than the raw otrasli today "[27]. But today, there are serious obstacles to such reformers. In this situation today MPs pocket Ukrainian oligarchs will not be allowed to raise several times the natural rent of raw materials. As it did in Azerbaijan and Russia. For example, in Azerbaijan oil provides about 70\% of the country's income. [29] And secondly, even many years will stand at the public trough, due to the existing political system, corrupt, hypocritical and sales Ukrainian elite. Which using handheld deputies received a huge profit not only from the public trough, but also on the shadow economy. [15] This elite really do not want to give up their fiscal and shadow profit on the development of high-tech industries. And it will repel young reformers from the supreme authority.

At accordance with the foregoing, a need for new studies with more objective forecasts and the specific terms of the future transformation of the Ukrainian political system and the Ukrainian political elite, in conjunction with the predicted timing the duration of the Civil War (or ATO) and world processes.

\section{A Main Study Material}

Conceptual principles our predictive research is based on the author's methodology postakademizma [10], [13], [11], including on the basis of five new, interconnected, conceptual installations, due to the methodological and systematic interaction of external and internal factors and vectors of transformation of modern Ukrainian the political system [15].

Based on the above methodology, and based on the method of extrapolation from the previous Ukrainian history of the twentieth and twenty-first centuries. [9], [12], can be divided into two main vectors (two forecast) the future of the Ukrainian political system format in the next 18 - 20 years:

\section{The I Vector - Peaceful Democratic Transformation of the Ukrainian Political System}

In the next 20 years Ukraine still will enter the EU, but will at the same time a third-rate European country with the lowest level of economic and social development. And with the lowest in Europe the level of the average wage and pensions (in the 30s of the XXI century). Thus, in accordance with the "Human Development Report" (UN Development Programme) in 2013, Ukraine took the last place in Europe in terms of the human development index [11]. A Civil War 2014-2016 it shifted the social and economic potential of Ukraine, including the index of human development, from the last place in 
Europe for the last places in the world. And the forecast for third-country in Europe is based on the possibility of a peaceful and stable democratic development of the Ukrainian political system after 2017, including the possibility of the Civil War (ATO). World political experience shows that "conservatives and radicals may be tired from the long struggle, or afraid that she will grow into a civil war. Fear of civil war, as a rule, becomes hypertrophied dimensions, if the company has gone through a similar civil war in the recent past "[19, p.399]. And this fear in Ukrainian conservatives and radicals increases not only because of the unpredictable civil war in the East of Ukraine in 20142017, but also in relation to the estimated possibility of future multi-million victims, as in the previous civil war in Ukraine in 1918-1921.

\section{The II Vector - The Transformation of the Ukrainian Political System in a TWENTY-Year Civil WaR}

The second "military" predictor of possible policy device is connected not only with the global crisis and a hybrid of a third world war, using Ukraine as an object of geopolitical struggle between Russia and the United States, but also with the possibility of lack of it modern leading Ukrainian politicians and oligarchs fear, with a predominance of " hawks "in the parliament requiring it modern continuation of the civil war to the bitter end, to the destruction of the last of the" Russian world "in Ukraine. And it could be a civil war lasting 20 years (2014-2034). To justify such a period, the duration of the Civil War will refer not only to the similar periods of the civil war duration in Afghanistan, Iraq and Syria, but also to use the method of extrapolation based on a comparison with the previous civil war on the territory of Ukraine. So, as it was at the Ukrainian Bolsheviks in 19181938. Who not only organized civil war against its own people in 1918-1921, And continued in 20-30 years. Twentieth century violent military means communist industrialization and "cultural revolution", the genocide of the Orthodox people of Ukraine in connection with the forced collectivization [8]. As Suvorov points out, "The collectivization was only possible under the machine-gun fire of the Workers 'and Peasants' Red Army" [20, p.194]. On the forced collectivization Ukrainian village uprisings said. For example, in March 1930 in Ukraine "was recorded $45 \%$ of the peasant uprisings ... in some villages escaped the trenches and were arranged outpost, joined the rebels in a gunfight with the death squads of the OGPU" [21, p.16]. The above-mentioned historical events, in conjunction with the artificial famine of 1932-1933 and the Great Terror in 1938 give reason to believe that a civil war with the Ukrainian Bolshevik own people did not last three years (1918-1921.), and as much as 20 years. During these twenty years have died: in the civil war of 19181921 - 1.5 million Ukrainians, famine 20s took to the grave of ethnicity 1.5 million Ukrainians in the Holodomor of 1932-1933 direct demographic losses totaled 4.6 million Ukrainians died [10, p.71]. Thus, the forcible conversion of the Ukrainian people in communism cost the lives of many Ukrainians, the total number of Ukrainian victims of the great civil war 1918-1938 is 7.6 million people.

This brief historio graphical information about the progress and results of the Ukrainian Bolshevik political violence and a great civil war 1918-1938. Ukraine is the basic foundation (and the first artifact) extrapolation method of comparison and forecasting anticipated the tragic consequences of a possible second largest Civil War 2014-2034 in Ukraine. This can happen if today Ukrainian nationalist "hawks" will continue the civil war in Ukraine, to the bitter end, to the destruction of the last of the "Russian world" in Ukraine, to the destruction of the last priest of the canonical Ukrainian Orthodox Church. And if the Ukrainian government will continue to use political and military violence to all dissidents, including those who do not want to be forced by civil war, "pulled" into the European Union, into a third European country. It is forecasting a possible second largest Ukrainian civil war, is also based on the basis of not only the epistemological forecasts proliferation of the global crisis, but also a genetic predisposition of Ukrainians to the anarchy and violence, to the militant mentality. Militant mindset came in the flesh and blood of many Ukrainians, not only during the great Civil War 1918-1938, but during the world wars, the civil war OUN and the UPA with the Soviet regime in the second half of the 40-ies of XX century. And this warrior mentality of the first community of militant Ukrainians peacefully side by side next to the callous mindset another large community of Ukrainians apathetic. Who are accustomed to do evil in the Bolshevik repressions and famines, during the German occupation in the First and Second World Wars. And these insensitive people we see not only in the peaceful streets of Ukrainian cities, but in the crowded concert halls, when dying Ukrainian soldiers under Ilovaiskaya, and at this time the people of Kiev peaceful jokes Vladimir Zelensky in "95th quarter". 


\section{V.Kuzevanov}

The second argument (and artifacts) to forecast the timing of possible duration it modern twenty years of civil war in Ukraine are the statistics on the average timing of political violence and the constant terrorist acts in it modern states - from 12 to 23 years [7, p.87].

The three argument "paramilitary" forecast possible second largest civil war in Ukraine in 2014-2034 is the ukrainian permanent feudal war in the XXI century between major industrial and financial groups (PFG) for the supreme (and regional) authorities, for control of the state budget "pie" and on the shadow economy.

The fourth argument (and the reason), economically contribute to the continuation of the civil war, it is the excess profits obtained Ukrainian oligarchs, as a result of military orders and military supplies in connection with the need to deliver in the area of fighting a huge amount of military equipment, ammunition and petroleum products (diesel, gasoline). As the saying goes, "Who war, and to whom your own mother." This allowed excess profits, for example, the regional oligarchic "Korban teamFilatova" not only to privatize (outbid) all Dnipropetrovsk mayor's office and city municipal hazyaystvo, not only actively participate in local elections in Chernihiv [17], but also to nominate G.Korbana future Kiev mayoral election. And if this candidate would become mayor of Kiev (this is possible because of the huge volumes of funds on public relations), it received not only Kyiv, but also its budget, which is several times higher than the budget of Dnepropetrovsk.

The fifth argument and the main catalyst of social tensions and political crises, revolutions and civil wars is obvious blatant social injustice in the form of a huge income gap between the richest and the poorest strata of the Ukrainian population. Especially it is necessary to allocate the period 2014-2015, when there was a sharp impoverishment of a large part of the Ukrainians because of the outbreak of the Civil War and the fall of the hryvnia (and enormous inflation). And in the years 2016-2017 this impoverishment has been exacerbated not only a significant increase in unemployment, and a sharp increase in utility tariffs, prices for food and energy. According to rough estimates, the level of income of the richest Ukrainians more than a hundred times the income level of the poor Ukrainians themselves living below the poverty line [14, p.124]. While in Western European countries, the average income of the richest $10 \%$ of Western Europeans more than just eight times the average income of $10 \%$ of the poorest layers of the population in Western Europe. And while the richest Ukrainians "voluntary" or "forced" does not share their profits with the poorest Ukrainians, in the next 20 years Ukraine will postoyanku shake the revolution and civil war.

The sixth argument against the use of the religious factor in the emergence of political instability and political crises, is the presence of external and internal forces using the most sectarian and mezhkonfessinalnye conflicts to destabilize the political situation in Ukraine. For example, the western Catholic expansion in Ukraine, dressed in a Uniate aggression UOC-KP is trying to eradicate the canonical Orthodoxy in Western Ukraine under the guise of fighting with the "Russian world", including on the basis of churches redistribution in favor of the UOC-KP [1]. Uniate aggression that began twenty years ago against the Orthodox communities of Galicia and Carpathian Ruthenia, now spread to areas like Volyn or skirts, and even predominantly Orthodox land, where the union never existed. And if today the Ukrainian Catholics and Greek Catholics, intolerant atheists, short-sighted "hawks" and "copper helmet" does not understand the danger of inter-religious conflict and do not aspire to the religious world, these specifically religious conflicts generated by them can spontaneously lead to uncontrolled religious war. Such religious wars we see today in Afghanistan, in many countries of Asia Minor, the Middle East and North Africa.

The seventh argument in support of the forecast of the possibility of the continuation of the civil war (ATU) is the increase in the level of Nazism in Ukrainian political culture. The well-known political analyst M.Pogrebinsky said: "The main thing here is that - in the context of the modern Ukrainian political culture of Nazism became part, absolutely do not blame part of that culture," [23]. But history knows where the Nazis, there - war.

And the eighth argument in support of the military of the Russian Federation are forecast claims of natural and mineral resources of Ukraine. Today, Ukraine is the richest country in Europe on the content of a variety of mineral resources, including reserves of iron and manganese ore, titanium and coal [15, p.104]. And so the Russian Federation actively supported the Ukrainian separatist forces to further unleashing the civil war in Ukraine and further rejection of Ukraine the most industrially developed regions with rich reserves of iron and manganese ore, titanium and carbon. 
A peaceful democratic transformation of the Ukrainian political system is based on the possibility of international support for Ukraine's democratic states in the fight against Russian aggression, freezing the military conflict with DNR and LNR, the conversion of the line of contact with the DNR and LNR in the actual border. In order to justify this option, the forecast of a possible twenty-year period (20172037) of peaceful democratic transformation of the Ukrainian political system and the Ukrainian political elite, we present the following arguments:

A. If the violent communist military modernization of the Ukrainian nation, with the first great civil war in 1918-1938, lasted 20 years, the reverse democratic, socio-psychological, legal, genetic and ideological return of the Ukrainian nation to the world of Christian civilization will also require at least 20 years. And the last 23 years of independence Ukrainian government (1992-2014) characterized by minimal democratic achievements and maximum characteristics of the postcommunist system, mirror the political system of his older brother - the Russian Federation.

B. Creating a full-fledged middle class, civil society and the democratic state in Ukraine, too, will require at least 20 years. This period mark the western politicians to create a civil society in developing countries [4, p.293].

C. The previous Ukrainian presidents, prime ministers and ministers of war the last 22 years methodically and purposefully disarmed the Ukrainian army, the most powerful European army in 1991. Will take at least 20 years to re-create and equip with the latest technology and new weapons and combat capability Ukrainian army, able to withstand any aggressor and to protect the peaceful democratic transformation of the Ukrainian political system (regardless of whether Ukraine will enter the European Union and NATO, or not come).

D. It will take at least 20 years to overcome the political crisis and the economic collapse of the antistress state of the Ukrainian society. As a sociologist O.Kopytko says "We expect a very rapid social, economic and political changes. In this case, the downside. That I bring as a separate option. Against this background, will operate all the trends at the same time - and the conflict in power, and activation of the new nascent opposition, and active intervention in the internal affairs of the country of our foreign colleagues' [24].

E. Ukraine will need at least 20 years to stabilize the political system, creating a full-fledged civil society and the middle class, for the further democratization of Ukrainian society, to the representatives of civil society and the middle class could create ideological political parties are standing on guard interests of civil society, the average class and working people. And in the next 10 years in the Ukrainian parliament and local councils to lead the political process will be the political parties pocket Ukrainian oligarchs, who with the help of subservient media, and non-transparent elections give the appearance of systemic reforms, democratic reforms and fight against corruption. Today, as noted by the Chairman of the Odessa Regional State Administration Mikheil Saakashvili, the Ukrainian government is controlled by the oligarchs, so it does not carry out real reforms [25].

F. Ukraine will need 20 years to half reduce the level of corruption and the shadow economy, to remove most big business and oligarchs from power. According to official data, in the first quarter of 2015 the level of shadow economy in Ukraine increased by 5\% to $47 \%$ of the volume of official GDP [26]. Today, the protection of big business, oligarchy, corruption schemes and the shadow economy are all power structures that protect big business, with its shady income from the possible development and strengthening of small and medium businesses. Particularly damaging to the emerging small and medium business is the activity of specially created to combat the emerging market economies, the tax police to destroy the small and medium enterprises. These "gendarmes", numbering 55000 employees of the tax police, constantly "suffocate" the existing and newly organized small and medium enterprises with the help of unjustified inspections of enterprises, including by means of removal of these enterprises financial and accounting documents during inspections. As a result of such unjustified inspections and removal of documents about 90 percent of these enterprises are forced to stop their production and financial activities. As noted by MP Andrew Zhurzhy, random inspection of 6000 tax inspectors showed that of the 2000 cases of violation of the tax legislation, which they brought before the court reached only 49 cases, or $2.5 \%$ of the criminal proceedings initiated by them [5].

G. It will take at least 20 years before selling the old and corrupt Ukrainian political elite will replace New Patriotic Democratic elite. And this new elite will eliminate the political, social, regional, inter- 


\section{V.Kuzevanov}

ethnic, inter-religious and international conflicts are not using machine guns, tanks and planes, but with the help of democratic and anti-corruption reforms, based on the elimination of big business from power, economic reform, the real expansion of the territorial rights communities and communities, local government and self-financing.

H. And only after 20 years, the new Ukrainian political elite, together with the company finally decided on the Ukrainian national idea and national priority in the economic component of the new Ukrainian political system. Including the definition and the main financial source for sustainable development of the Ukrainian economic system and the welfare of the Ukrainian people. Whether due to the withdrawal from a major capital of natural monopolies, as is done in the Gulf countries, Russia and Azerbaijan. Or due to financial subsidies from the European Union and the United States (The new "Marshall Plan"). Or due to the development of agricultural production and the transformation of Ukraine in the first agrarian European country. Or due to the headship of postmodernity advanced technologies.

I. And in the geopolitical perspective, while Ukraine will not overcome the oligarchic power and corruption, not to build a democratic society and the most powerful army in Europe, it is in the next 20 years will not be admitted to NATO and will remain an American satellite, the object and the center of the geopolitical struggle between the United States and the Russian Federation. And you must wait at least 10 years to the world of anti-Russian political and economic sanctions on Russia collapsed. Just as the USSR collapsed from the global anti-Soviet political and economic sanctions after the Soviet invasion of Afghanistan.

K. Finally, Ukraine will take time and huge investments to modernize the industry and the transition to technical and economic standards and regulations of the European Union. Since the cost of implementation of the technical and economic requirements for joining the EU is a huge - more than 100 billion euros. However, foreign investment in the reconstruction of Ukrainian enterprises will go only when we win corruption and oligarchy. And as noted by the chief auditor Mikhail Dnepropetrovsk Krapivko "if the government will look for themselves" loopholes "that the EU we are not any closer in ten, or twenty, or fifty years" [28].

\section{FINDINGS}

Introduced twenty Political Studies forecast the possible development of the Ukrainian political system and the necessary regeneration of the Ukrainian political elite (in 2017 - 2037) includes two main possible options for the development of these political processes (military and peaceful democratic). Other areas are unlikely if you follow sound scientific methodology of political science knowable world and European political processes. And if you follow certain existing rational logic and direction of the vector existing political processes in the world. There is not only today but also possible in the next 10 - 50 years. In conjunction with the currently existing global political crisis and the ongoing hybrid World War, including the territory of Ukraine. And these external causes of the global crisis will condition the military version of the future development of the Ukrainian political system, including the option of self-destruction of the Ukrainian nation with the help of the Civil War until World political crisis has reached its climax. Therefore, our findings is not rosy picture solemn Ukrainian integration into the Western world, in the European Union. Therefore, we agree with the leading contemporary political scientists and sociologists, who understand own Ukrainian political system and the internal political crisis in every country of the world through the prism of the political crisis. This methodological approach is rational in political science and sociology allows more objectively assess the current political crisis in the country and the world, as well as to predict the transformation of its political system, not only in relation to the global political processes, but also in conjunction with its previous history. Therefore, political science, our findings are consistent with a critical analysis of the Ukrainian (E.Kopytko, V.Shedyakov) and Western sociologists. For example, a researcher I.Vallerstayn global crisis through the prism of it modern world-system, and that "... the historical system has entered the stage of ending the crisis and is unlikely to exist in fifty years" [2, p.5].

$\mathrm{V}$ accordance with the above, it should be noted that the two main predictions possible transformation of Ukrainian politics for the next 20 years is the most probable forecast for the military. Because today and in the next 10 years, external factors and political processes affect (and will be affected by) the political transformation in Ukraine is much stronger internal factors and processes of the global 
crisis and heightened geopolitical struggle of the leading states for world domination, for a very rich natural and mineral Ukraine resources. Including due to the geopolitical aspirations of China and the United States to weaken the position of the Russian Federation in the international arena, due to China and the United States claims to world domination. Today, Ukraine is not only anti-Russian bridgehead, not just a bargaining chip in a third world hybrid war against Russia, but also specially created suffocating "Western Ukrainian dead loop" on the "neck" of the Russian Federation. Just as in 1914-1917, "German dead loop" was a killer for centuries the Russian empire (and this "loop" has been thrown over with the help of Britain and the USA). And in the 80s of the twentieth century "Afghan dead loop" became deadly for the Soviet Union from the world anti-Soviet political and economic sanctions and the economic collapse that followed the military aggression by the Soviet Union in Afghanistan. Today, "Ukrainian dead loop" all the more delayed on the "neck" of the Russian Federation. And do not believe the "yellow press" of the brilliant operations of the General Staff of Russia for lightning-fast "blitzkrieg", seize the Crimea and eastern regions of Ukraine. And you have to believe the historical facts and the fact that the "blitzkrieg" and the apparent insecurity of Ukraine was a mousetrap and a piece of fat, with which the Western countries have placed over the neck of the Russian Federation "Ukrainian dead loop". And you have to believe the economic facts about the devaluation of the Russian ruble, the stagnation of the Russian economy and the impoverishment of the Russian people in three years after Russia invaded Crimea and Donbas were Russian tanks and Russian military instructors.

\section{BIBLIOGRAPHY}

[1] Alexandrova M. Crusade: in Western Ukraine is a redistribution of churches // Vesti. Reporter2015.-No.19-P.42-45.

[2] Wallerstein I. End of the familiar world: Sociology of the XXI century / Immanuel Wallerstein / Trans. With the English. Ed. VI Inozemtseva. - Moscow: Logos, 2004. - 368p.

[3] Vinnychuk O.V. Oboblivosti transformatsii politicchnyh tsinnost Ukrainskogo suspilstva u postrevolyutsiyny period // News of the Dnipropetrovsk University. Series Philosophy, Sociology, Political Science: collection of scientific works.-D .: Publisher Innovation, 2015 No.1.-P. 33-41.

[4] Inglehart R. Postmodern: changing values and changing societies / Political Science: Reader / comp. BA Isaev, AS Turgaev, AE Khrenov.-SPb .: Peter, 2006.-P.286-301.

[5] Zhurzhiy A. The Ukrainians did not obey the year 55000 employees in the tax office // Newspaper "On* Samopomich Union" .- 2015.-№37.-P. 3.

[6] Kaplan M. System and process in international politics / Political Science: Reader / comp. BA Isaev, AS Turgaev, AE Khrenov.-SPb .: Peter, 2006.-P.451-452.

[7] Kravchenko V.Yu. Socio-economic determinants of political violence//journal of Dnipropetrovsk University. Series Philosophy, Sociology, Political Science: collection of scientific works.-D .: Publisher Innovation, 2015 No.1.-P. 81-90.

[8] Kuzevanov V.M. And was there a genocide of Orthodoxy in Ukraine? // Philosophy. Culture. Life: interuniversity collection of scientific papers.-Issue 33.-Dnipropetrovsk: Dnipropetrovsk Finance Academy, 2009.-P. 21-28.

[9] Kuzevanov V.M. Determining events of the history of Ukraine of the twentieth century // Grani.2012.-№5.-P.25-34.

[10] Kuzevanov V.M. The post-academic process of the crisis of world history and its Ukrainian mirror image / Suasnny socially-humane discourse. Mater. IV alluk. Sciences. Confer. 3 міжнар. Participant of the m. Dnipropetrovsk, 22 birch in 2014: in 3 parts.-D.: LLC "Innovation", 2014.p.I.-P.70-73.

[11] Kuzevanov V.M. Postcommunist political institutions in Ukraine against the background of postacademism / Pridniprovsky socially-humane chitannya. Mater. III allukr. Sciences. Confer. 3 міжнар. Participate. (M. Dnipropetrovsk, 29 leaves of the fall of 2014): in 4 parts.- D .: LLC "Innovation", 2014.-p.1.-P.44-47.

[12] Kuzevanov V.M. The role of Ukrainian social democrats in the modernization of the Ukrainian nation // Grani.-2013.-No.2-P.62-67.

[13] Kuzevanov V. The tragic period of Ukrainian modern history / Introduction to postacademism // Arkasivsky chitannya: the material of the IV International Scientific and Practical Conference (11-12 quarters of 2014) .- Mykolaiv: MNU iomeni VO Sukhomlinsky, 2014.- P.172-174. 
[14] Kuzevanov V.M. Transformation or degradation of politics: to an attempt to find a politicalregional consensus (the methodology of the problem) // The Humanitarian Journal. 2005.-№3.P.122-125.

[15] Kuzevanov V.M. Expert-comparative analysis of the causes of the political crisis // News of the Dnipropetrovsk University. Series Philosophy, Sociology, Political Science: collection of scientific works.-D .: Publisher Innovation, 2015 No.1.-P. 98-108.

[16] Lyasota A.E. Especially the process of modernizatsii інститутів громадянського суспільства в Україні // Modern socio-humanitarian discourse. Mater. V Vseukr. Sciences. Confer. With int. Participate. M. Dnipropetrovsk, 21 birch of 2015: in 5 parts. -D .: LLC "Innovation", 2015.-part I.-P. 37-39.

[17] Nikolayenko I., Paschenko V . Autumn will be hot // Newspaper "Gorozhanin.-2015.-№37.-P.2.

[18] Pavlenko Yu.V. History of World Civilization. Philosophical analisis.- K .: Phoenix, 2002.-760p.

[19] Rastow D. Transitions to Democracy: an attempt of a dynamic model / Political Science: Anthology / comp. BA Isaev, AS Turgaev, AE Khrenov.-SPb .: Peter, 2006.-P.394-403.

[20] Suvorov V. Purification: Why did Stalin decapitate his army? -M .: Ltd "Firma" Izdatelstvo AST ", 1998.-480 p.

[21] Khlevnyuk O.V. Master. Stalin and the approval of the Stalinist dictatorship. - M .: The Russian Political Encyclopedia (ROSSPEN); 2010.-134s./Www.upload.Studwork.org/ order/ 180952/ Stalin.pdf.

[22] Shedyakov V.C. Strategičnu manages the processes of post-hour transformations for the additional information influences the socio-political level//Herald of Dnipropetrovsk University. Series Philosophy, Sociology, Political Science: collection of scientific works.-D.: Publisher Innovation, 2015 No.1.-P. 248-259.

[23] http://regnum.ru/news/ polit / 1968767.html.

[24] http: // rian.com.ua/ interview / 20150223 / 363874254.html? Utm_medium = referral \& utm_ source $=$ lentainform $\&$ utm $\_$campaign $=$rian.com.ua $\&$ utm_term $=135137 \&$ utm_content $=$ 3393820.

[25] https://news.mail.ru/politics/23195820/?frommail=1.

[26] Newspaper "Vesti", 2015.-No.145.-P.3.

[27] Newspaper "The Day" .- 2014.-No. 100.-P.7.

[28] Newspaper "Dnepr Evening", July 18, 2014-P.7.

[29] Newspaper "The Mirror of the Week" .- 2013.-No. 37.-P.3. 